\title{
European Union Non-governmental Organizational Coalitions as Professional Social Movement Communities
}

\section{Pauline Cullen}

To cite this article: Pauline Cullen (2015) European Union Non-governmental Organizational Coalitions as Professional Social Movement Communities, Journal of Civil Society, 11:2, 204-225, DOI: $10.1080 / 17448689.2015 .1052228$

To link to this article: http://dx.doi.org/10.1080/17448689.2015.1052228

曲 Published online: 16 Jun 2015.

Submit your article to this journal $\widetilde{ }$

Џ Article views: 218

Q View related articles $\widetilde{ }$

View Crossmark data $\nearrow$

Citing articles: 1 View citing articles $\longleftarrow$ 


\title{
European Union Non-governmental Organizational Coalitions as Professional Social Movement Communities
}

\author{
PAULINE CULLEN \\ Department of Sociology, Maynooth University, National University of Ireland Maynooth, Maynooth, Ireland
}

\begin{abstract}
Previous analysis has looked at the interface between organized civil society (OCS) and European Union (EU) institutions and has posed questions about their role as political communicators for the EU project, and consequently their independence, representativeness, and policy influence. While these accounts focus in part on the role of European OCS in helping the $E U$ institutions in the process of identity building, this work differs in offering an account of the internal processes that build identification and community within EU OCS coalitions. These dynamics are examined using social movement theory on coalitions and communities applied to a diverse coalition of OCS working on a range of social change issues at EU level known as the Platform of European Social NGOs (the Platform). Aside from a broad ideological alignment based on support for a stronger social policy at EU level, the composition of the Platform remains diverse. While diverse organizations can cooperate effectively in loose episodic and strategic alliances, the continuity in and density of collaboration within this coalition are notable. In the process of coalition work Platform members are influenced by external frames that circulate at EU level; they are also involved in a process of community building that has emerged between organizations grappling together to develop a shared understanding of an issue and an agreement around its strategic communication. Through an analysis of coalition structures and outputs, this article contributes to debates on transnational OCS coalitions by exploring the conditions for continuity, survival, and the generative properties of coalitions which move transnational civil society actors beyond purely ad hoc and instrumental, coordinated action to more durable identity-based forms of collaboration.
\end{abstract}

KEY WORDS: Coalitions, organized civil society, European Union, non-governmental organizations, collective identification, community

Correspondence Address: Pauline Cullen, Department of Sociology, Maynooth University, National University of Ireland Maynooth County Kildare, Maynooth, Ireland. Email: pauline.cullen@nuim.ie

(C) 2015 Taylor \& Francis 


\section{Introduction}

European Union (EU) level non-governmental organizations (NGOs) are important components of a broader network of European organized civil society (OCS) groups that operate within dense networks of information exchange and policy communities populated by national- and local-level social movements, academics, experts, think tanks, and EU and national political elites (Bee \& Guerrina, 2014; Ruzza \& Bozzini, 2008). Most analyses of EU NGOs focus on questions regarding their capacity to improve the quality of democratic practice, their vulnerability to cooptation through their receipt of EU funds and ultimately their potential to influence policy-making (Bee \& Guerrina, 2014; Cullen, 2010; Geyer, 2001; Greenwood, 2007; Kohler-Koch \& Quittkat, 2013; Kroger \& Friedich, 2013; Ruzza, 2011). What has already been established for these organizations is that their institutional context has a strong structuring influence on their claims making and that forces of selection and incorporation have narrowed their strategies (Cullen, 2005; Dur, 2008; Trenz, 2009). Another analysis has argued that while restricted in large part to insider tactics, the construction of coalitions of interest between EU NGOs has enabled these actors to mobilize in effective ways to influence EU policy processes (Cullen, 2005; Kendall, 2010; Ruzza, 2004, 2011). Ruzza (2004, 2011) assesses these forms of alliance building as now constituting a form of associational ecology and multiorganizational field at EU level. Coalitional arrangements between EU NGOs are in turn supported by EU officials who view them as their preferred avenue for consultation as the EU NGOs constitute from their perspective an access point to an aggregation of interests from across European societies. This article takes stock of these processes of alliance building, explores how far this collaboration has evolved, and assesses whether it can now be understood as constitutive of a form of community.

The work of Aunio and Staggenborg (2011) on coalitions and transnational social movement communities and analyses of collective identification within the global justice movement (Flesher Fominaya, 2010; Hewitt, 2011) are used here to assess the mechanisms of collaboration and processes of collective identification that have emerged between a diverse coalition of NGOs working on a range of social change issues at EU level known as the Platform of European Social NGOs (the Social Platform or the Platform). The Platform is an EU-sponsored coalition of diverse European NGO networks and federations of voluntary and social welfare organizations formally launched in 1994 with six members to promote a semi-institutionalized dialogue between NGOs, EU institutions, national governments, and labour and employer interests on social policy matters. The Platform's official functions are to facilitate informational exchange between its NGO members, encourage their adoption of common policy positions, and engage in regular consultation with the EU on social policy matters.

Aunio and Staggenborg (2011) define a social movement community as a network of interactions among individuals, movement organizations, cultural groups, and institutional supporters that share a collective identity and seek to advance movement goals. One of the forms they recognize is that of a professional social movement organization (SMO) community that includes professional activists associated with international governmental organizations (IGOs) and international NGOs (INGOs), grassroots activists participating in SMOs, and movement supporters among the public. Applying this concept to NGOs that mobilize in coalitions around the institutions of the EU allows for an assessment of the patterns of collaboration and forms of collective communication that increasingly 
characterize NGO work on the transnational level. This analysis also affords an exploration of how processes of Europeanization work to create new strategic but also epistemological opportunities for EU-level OCS.

EU social NGOs are relatively resource-poor and weak actors in the larger context of lobbying and advocacy around the EU institutions. In the context of large asymmetries in power within the political opportunity context, it is common for less powerful actors to work together to reduce costs, increase legitimacy, and maximize impact (Guiraudon, 2001; Yanacopulos, 2005). However I argue that the 'coalition work' undertaken by the Platform facilitates forms of social interaction and social ties that suggest a form of cooperation that is different from a largely instrumental coalition (Diani, 2013). Through collaborative action or 'coalition work' a form of imagined collective identity develops that distinguishes these relationships from more ad hoc and less coordinated forms of alliance (Diani, 2013; Melucci, 1995). While in the process of coalition work Platform members are influenced by external frames deemed salient to their cause, they are also involved in a process of community building constituted in part by the use of frames that communicate a united front for external audiences but work internally to provide a space for capacity building across organizational, cultural, and sectoral boundaries. The production of an external-facing form of collective identification and community is essential in a resource-competitive and politically complex multilevel governance environment, where EU social NGOs have less power than other private interests mobilizing around the EU institutions.

Although this collective identification is most likely not evenly or uniformly experienced by coalition members or in itself a requirement for many forms of coalition that Platform members engage in, it does mark a form of continuity in identification over time (Diani \& Bison, 2004; Diani \& Pilati, 2011). However, it is important to note that the construction of a community of EU social NGOs is a goal supported in particular by the Platform secretariat for which acts of community are understood to be an important organizational objective. Notably what is constructed here is more of a community of interest rather than a community of equals, and power asymmetries shape coalition dynamics and community-building processes.

This article is divided into three parts. The first details the method and case and then reviews social movement scholarship on organizational coalitions and social movement communities, arguing that the location, repertoires, and network structures of the Platform and its members allow them to be understood as a form of transnational professional SMO community. Next an exploration of the concept of collective identity and Platform working group structures and position papers allows for an assessment of whether the Platform meets the other criteria for a professional SMO community, i.e. the existence of a form of collective identification understood as a precondition for community. In the third part of the article social movement concepts of framing and collective identity are employed to make sense of the coalition's use of internal and external framing, communicated here through a combination of oppositional and internally focused frames, for the Platform's strategic objectives and long-term sustainability. This latter point is timely in that austerity and the neoliberal framework of the EU project more generally mean that the long-term prospects of significant financial support for this sector are under threat, which may have implications for members' capacities and motivations for collaboration. It is within this hostile political opportunity context that NGO coalitions can benefit from a form of community as coalitions act as a form of political cover. 
This work argues for a focus on the interactions and substantive collaborations between EU NGOs as a contribution to more theoretical efforts to assess the influence, representativeness, and democratic potential of these civil society groups at EU level.

\section{The Social Platform: Methodological and conceptual considerations}

Document analysis was the predominant method employed and was informed by interview data to make sense of the understandings and experiences of Platform staff and members as they interact and collaborate to shape EU policy through common campaigns. Internal organizational dynamics and external organizational communications were analysed on the basis of documents including minutes of working group meetings, press releases, policy positions, and annual reports. Publicly available documents were accessed from the Social Platform website and other internal documents were supplied by its secretariat and its member organizations.

Interview data provide insights from the perspective of key EU officials, Platform secretariat members, and some key members of the coalition. Purposive sampling was used to select interviewees. Interviews were conducted with two officials from DG Justice Fundamental Rights and Citizenship in September 2011. Face-to-face and telephone interviews were conducted with Social Platform policy and advocacy advisors in September 2011, August 2012, October 2013, and May 2014. Additional interviews were conducted with directors of four NGO Platform members, two from the social service sector and two from the anti-discrimination sector, who asked to remain anonymous due to the sensitive nature of their contributions. Participants offered assessments of the evolution of the Platform, its current position as an interlocutor on social policy issues at EU level, and their experiences of participation in working groups and collaboration on campaigns.

The advantages of combining interview data and document analysis lay in possibilities to explore the motivations behind specific organizational priorities and strategies. It also allowed for an assessment of members' efforts to reach forms of shared understanding and ultimately the frameworks employed by the Platform in communicating its position to its membership and externally in EU institutional contexts. The limitations are those attendant to small sample size case study research that cannot provide a comprehensive review of an organization's activities or an audit of its entire membership but rather an in-depth, if partial, account of organizational dynamics (Berg, 2007).

\section{The case: The Platform}

The Platform emerged in the early 1990s during a period of support within the EU institutions, specifically the European Commission, for the development of an EU social policy. Founding members seized this opportunity, securing funding and an agreement with the EU institutions to extend a form of consultative status to its members on social policy issues. The intervening years saw growing complexity in the opportunity context for its members with the demotion of social policy as an EU priority at the same time as an extension of EU competencies in a range of public policy areas of interest to its members. While the coalition grew in membership, rationalized its structures, and professionalized its secretariat, it also experienced periodic threats to its funding and significant internal disagreements rooted in contests over ideology, strategy, and competition for resources (Cullen, 2010). The EU is the main funding source for the coalition and many 
of its members. ${ }^{1}$ While stratification still exists between larger and smaller coalition members and ideological and strategic tensions shape coalition dynamics, the Platform has survived for 20 years and now includes 49 organizations. $^{2}$

The Platform is characterized by the diversity of its membership (see Table 1). Around $40 \%$ of Platform members declare themselves as advocacy groups, while over a third identify as service providers (Johansson \& Lee, 2012, pp. 11-14). One of the most notable cleavages within the Platform is between social service providers-some with faith-based orientations - and organizations advocating on equality and anti-discrimination issues including feminist, sexual minority, and anti-racism NGOs. ${ }^{3}$ For example the European Women's Lobby (EWL), a founding Platform member, is a feminist organization that holds a different understanding of what constitutes a family than COFACE, a more traditionally oriented family rights organization. CARITAS, the Catholic social service and social justice organization, also holds very different views on a range of issues related to sexuality and sexual orientation than another Platform member, ILGA Europe (European affiliate of the International Lesbian, Gay, Bisexual, Trans-, and Intersex Association). While most members share then a similar strategic orientation, the fact that they are active in different policy sectors and represent a range of constituents in turn affects their conceptualization of social problems. While diverse NGOs can cooperate effectively in loose episodic and strategic alliances, the continuity in and density of collaboration within this coalition are notable. Importantly, despite this diversity, Platform members can be arranged along a continuum of broad ideological alignment based on support for a stronger social policy agenda at EU level and variants of an anti-neoliberal perspective. As Kendall (2010) suggests,

The Social Platform has proved effective and durable in institutional terms bridging diverse NGO constituencies through intelligent, reflexive framing of the social policy agenda in ways which would simultaneously appeal very broadly across both reformist and conservative strands of the third sector. (p. 50)

Making sense of how this variegated political formation can cohere in such a sustained manner leads us to explore the relationship between ideational, identity, and instrumental elements in coalition formation and maintenance. In what follows I theorize and explore in empirical terms how sustained interaction over time between organizations on substantive issues facilitated a deepening of a common broad ideological agenda that in turn facilitated a form of imagined collective identity and community. This form of collective identification and community is constituted in the act of coalition, shaped by the instrumental or organizational objective to strengthen the EU social NGO sector, by ideational commitments to the EU as a venue for social justice and redistribution and by the diffusion of expertise and a form of common identification.

\section{SMO coalitions and communities}

A coalition's durability and depth are issues that social movement scholars have examined in research on the role played by the structure of social ties and networks, shared ideologies and frames in coalition formation and survival (Maney, 2012; Staggenborg, 2010, 2013; Van Dyke \& McCammon, 2010). This work has established that the conditions 
Table 1. List of member organizations of the Social Platform (as of May 2015)

AGE Platform Europe

Autism Europe

Caritas Europa

ATD Quart Monde-Fourth World Movement ${ }^{\mathrm{a}}$

CECODHAS-Housing Europe

CECOP-CICOPA Europe-European Confederation of Workers' Co-operatives, Social

Cooperatives, and Participative Enterprises

CEDAG-European Council for Non-Profit Organisations ${ }^{\mathrm{a}}$

COFACE - Confederation of Family Organisations in the EU

Dynamo International-Street Workers Network

EAEA-European Association for the Education of Adults ${ }^{\mathrm{a}}$

EAPN-European Anti-Poverty Network

EASPD-European Association of Service Providers for Persons with Disabilities

EBU-European Blind Union

ECDN_European Consumer Debt Network

EDF-European Disability Forum

EUCDN-European Community Development Network ${ }^{\mathrm{a}}$

ENAR-European Network Against Racism

ENSIE-European Network of Social Integration Enterprises

EPA-European Parents' Association

EPHA-European Public Health Alliance

EPR-European Platform for Rehabilitation

ESAN-European Social Action Network

EURAG-European Federation of Older Persons

EUROCHILD

EURODIACONIA-European Federation for Diaconia

ERIO_European Roma Information Office ${ }^{\mathrm{a}}$

EFOMW-European Forum of Muslim Women ${ }^{\mathrm{a}}$

EUROCARERS-European Association Working for Carers ${ }^{\mathrm{a}}$

EWL-European Women's Lobby

FAI-The International Federation of Christian Associations of Italian Workers

FEANTSA-European Federation of National Organisations working with the Homeless

FEFAF-European Federation of Parents and Carers at Home

ICSW-International Council on Social Welfare Europe

IFSW-International Federation of Social Workers Europe

ILGA Europe-The European Region of the International Lesbian, Gay, Bisexual, Trans- and Intersex Association

INCLUSION EUROPE-The European Association of Societies of Persons with Intellectual Disability

IPPF-EN-International Planned Parenthood Federation European Network ${ }^{\mathrm{a}}$

IUT-International Union of Tenants

MHE-Mental Health Europe

PICUM-Platform for International Cooperation on Undocumented Migrants

Red Cross EU Office ${ }^{\mathrm{a}}$

SOLIDAR

TGEU-Transgender Europe

VOLONTEUROPE

WAGGGS-World Association of Girl Guides and Girl Scouts Europe Region

YFJ-European Youth Forum

YES Forum-Youth and European Social Work Forum ${ }^{\mathrm{a}}$

${ }^{\mathrm{a} A s s o c i a t e}$ members. 
that allow for the emergence of coalitions such as threats from the external context may differ from those that allow for continuity of coalitions. Threats are likely to influence the timing of coalition emergence and a shared adversary may allow groups to collaborate without sharing a broader ideology, but this only lasts so long (Bandy \& Smith, 2005; Van Dyke \& McCammon, 2010, pp. 1292-1293).

The size of the coalition and the diversity of its membership are also relevant factors that influence how members evaluate the benefits and risks of collaboration. Research suggests that although SMOs may lose visibility in large coalitions, they also stand to gain legitimacy in new areas and to make valuable contacts (Staggenborg, 2010, pp. 322-324). In instrumental terms, membership of the Platform has enabled organizations to acquire expertise on and access to EU social policy-making processes and is supported by the secretariat and members through a formal organizational goal of creating a cohesive EU social NGO sector. Collaboration between SMOs facilitates the transfer of knowledge between organizations, the acquisition of new expertise, and the diffusion of tactics (Wang \& Soule, 2012).

However, ideational factors also shape coalition membership and maintenance particularly amongst diverse groups of organizations. Some scholars have identified ideology as a core element that allows social movement organizations to aggregate in what are termed social movement families (dellaPorta \& Rucht, 1995). This work has focused specifically on identifying ideological coherence or compatibility across different social movement organizations that emerge at a similar point in time and draw on common repertoires and collective action frames (dellaPorta \& Rucht, 1995). McCright and Dunlap (2008), in their analysis of the social bases of progressive social movement ideology, argue that the presence of a common ideology is a key element in orienting diffusion processes within a movement family. Their emphasis on the role played by movement ideology in allowing social movement organizations to cohere in strategic terms is useful in placing ideational factors at the centre of a treatment of social movement communities. Intermovement diffusion of ideology and tactics is multifaceted and involves sharing personnel, overlapping social movement communities, and organizational coalitions that share a common master frame that works as a central ideational element of an enduring ideology (McCright \& Dunlap, 2008, p. 382).

The coalition work explored below reveals how Platform members from the two main groupings or social movement families, i.e. anti-discrimination NGOs and service provider NGOs, collaborated in a broader social movement organizational community of EU social NGOs. Anti-discrimination NGOs (women's rights, anti-racism, sexuality, and disability rights) are clearly identifiable allies in ideational terms. Social service provider NGOs (mental health, intellectual disability, faith-based social justice, anti-poverty, etc.) have less explicit ideological coherence but do share a common commitment to social inclusion and social policy at national and EU levels. Collaboration on substantive issues across this divide required the deepening of existing broad ideological similarities through the construction of shared meanings and frames on carefully chosen transversal issues. The emergence of an overarching ideological framework has in this case facilitated processes of capacity building, collective identification, and community. My overall argument is that, while ideological (ideational) factors remain an issue for such a diverse coalition, instrumental concerns (capacity building/shared understandings) and the production of a deepened collective ideational framework have allowed for a collective identification and community to evolve. 
Applied to the EU context Ruzza (2011) argues that civil society coalitions do not necessarily alter the main identity of movement participants; rather, what is generated from such forms of collaboration can have important implications for modes of conceptualization and the analytical lenses employed by specific organizational members. In short, organizations can learn from each other. For Platform members, learning from each other and mobilizing together have over time allowed a form of collective identification to emerge. Rather than a deep sense of personal or social identity that may accompany long-term activism at grassroots level, this form of collective identification is rooted in professional social ties, common ideology, and shared organizational and professional socialization specific to the Brussels-based habitus (Favell \& Guiraudon, 2011). In this context, the earlier work of negotiation and compromise required at the beginning of a coalition have over time allowed for familiarity, shared understandings, and trust to develop as a set of coalition-based practices, perspectives, and identifications emerges (Van Dyke \& McCammon, 2010). Ultimately it is the role of this coalition work and the forms of collective identification that emerge from such engagement that underpin a sense of community that helps to sustain coalitions. In other words, while there are elements of community that emerge in the formation of a coalition, over time coalitions themselves foster further development of community.

\section{The Social Platform as a professional SMO community}

While research on coalitions tells us about how coalitions emerge, develop, and decline, work that looks at the structural or organizational and interactional context of coalitions under the rubric of community is helpful in making sense of how diverse organizations coalesce to maintain a consistent range of movement engagements across a field of action (Staggenborg, 1986,1988; Staggenborg \& Taylor, 2005, p. 40). Building on earlier work on social movement communities that assessed movement coalitions in this vein at the national and local level, Aunio and Staggenborg (2011) have more recently speculated on how these processes work in the transnational domain. In their conceptualization professional activists associated with IGOs and INGOs, grassroots activists participating in social movement organizations, and movement supporters among the public are all members of a transnational social movement community. The central element of community membership is a sense of shared identity understood at the transnational level as dependent on a form of 'imagined community' formed through social ties, collaboration on common campaigns, and participation at international conferences (Aunio \& Staggenborg, 2011, pp. 365-367). ${ }^{4}$ Of relevance here is the professional social movement community, composed of SMOs and institutionally engaged activists embedded in professional and social networks operating in multiorganizational fields of action.

According to Aunio and Staggenborg,

Institutionalized through their participation in the UN and other global institutions, professional movement communities are comprised of stable networks of professional activists with expertise on a range of movement issues. In addition to maintaining movements by ongoing lobbying and public relations work, they help to mobilize grassroots and conscience communities by keeping movement concerns on the public agenda and by alerting movement constituents to new issues. (2011, p. 6) 
Aunio and Staggenborg claim that professional SMO communities are distinguished by their use of contained as opposed to transgressive contention, the inclusion of knowledge brokers and groups that practice 'information politics'. They contend that through the act of collecting and disseminating information on salient issues, professional SMOs participate in the all-important process of problem definition and may develop 'epistemic communities' that leverage expert knowledge on behalf of principled ideas.

The Platform enjoys forms of insider access to the regular venues of transnational politics and institutionalized policy-making. Tactics employed include lobbying officials and politicians and the preparation of tool kits for use by national- and local-level members. In this way the Platform plays an epistemic role that is acknowledged in a tradition of formal and informal consultations, commonly referred to as civil dialogue, that exist between its NGO members, EU officials, and Parliamentarians. ${ }^{5}$ These functions and tactics suggest a fit between this coalition and many of the elements that characterize a professional SMO community.

An additional element of the concept of professional SMO community is the existence of professional leaders who use their expertise within international institutions to develop networks particularly in the context of campaigns (Aunio \& Staggenborg, 2011, p. 368). The Platform's secretariat, director, and the leaders of its member organizations have been instrumental in constructing durable networks for intelligence gathering, sharing, and capacity building across the EU civil society sector more generally (Cullen, 2005, 2010; Johansson \& Lee, 2012). Another characteristic of a professional SMO community is that while they develop in international fora they possess the capacity to shift advocacy work 'up' or 'down' depending on the campaign at hand. Platform campaigns are tied to the serial EU presidencies that shift between member countries in six-month cycles and now work in a trimester process that this coalition shadows as a means to influence EU but also national policy formation. The fact that most EU social NGOs are composed of national chapters or affiliates suggests the potential for a feedback loop that can be variable in its participatory quality but may allow for the transfer of information and expertise from both directions. EU social NGOs are also typical of most professionalized NGOs in having strong institutional structures, resources, and professionalized staff who coordinate often with one another within international venues and in social movement campaigns. In short, in organizational terms, its networked structure, tactics, and output together suggest a fit between the Platform and many of the characteristics of a professional SMO community.

However, simple participation in an international event or consultation on matters of policy does not denote community. Participants must establish and maintain networks over time in order to develop the collective identity so essential to the construction of a community (Aunio \& Staggenborg, 2011, p. 368). Direct ties are essentially reinforced through regular contact that in itself facilitates the construction of strong networks. In this respect, regular, routinized participation in collaboration fosters long-term engagement at the international level that helps professionals build mutual trust, support, institutional knowledge, collective identity, and thus community (Aunio \& Staggenborg, 2011, pp. 369-370).

Platform members do meet frequently as a function of their membership in a series of working groups but also as a consequence of the fact that some of the members hold membership of their coalition partners. For instance, the European Disability Forum (EDF), an important player in the Platform, has a women's rights committee that also holds membership in another Platform partner, the EWL. This is but one example of the overlapping 
nature of membership patterns that reinforce the density of interactions and network ties and the flow of communication across and between organizations. Simply put, Platform members encounter each other frequently in face-to-face and virtual interaction as they navigate the EU political context. In empirical terms, the Platform stated that in 2013 it held 8 skills-sharing or capacity-building seminars and 37 internal meetings. Interviewees indicate that outside of this official count they attended additional working group meetings and smaller 'side' meetings or contacts with other members on issues raised as part of campaigns associated with the coalition (Social Platform, 2014a; Interview with Platform member, September 2012; Interview with secretariat, September 2013 and May 2014).

Whereas a policy network suggests a group of actors aligned by mutual interest and resource dependence, a professional SMO community denotes a more stable set of relations that rest on the crystallization of a form of collective identity (see Table 2). In what follows I explore the structures and outputs of the Platform to understand dynamics of collective identification and community.

\section{The Platform and collective identity formation}

The evolution of the Platform across a 20-year period from its origins as an ad hoc talking shop to its current shape as a formalized and legally established entity with its own internal rules, membership criteria, and governance structures is reflective of a trajectory of community building across the EU social NGO sector. As one of the directors of a long-standing Platform member remarked,

There is now in the Platform a sense of community and of shared purpose, this was not always the case but enough time has now passed that even when there is a turnover of personnel you can still feel that there is that understanding that you don't have to go back to the beginning on everything and we don't have to agree on everything; we can still share a sense of community. (Interview with Platform member September 2011)

This sense of shared purpose was not an easy or inevitable consequence of the proliferation of NGOs at EU level but was rather the outcome of the work of its members and secretariat

Table 2. The Platform of Social NGOs as a professional SMO community

Professional SMO community Platform of Social NGOS

\section{Location}

International meetings, conferences, events

\section{Repertoires}

Information politics, lobbying, networking, contained contention

Network structure and ties

Transnational network of organizations, strong ties formed through collaboration, high network density

Transnational context, bilateral working groups, general assembly, and campaignbased events

$\checkmark$ Common positions, invited inputs and consultations, press releases

Umbrella for transnational network, overlapping memberships, mini-coalitions, bilateral and multilateral alliances 
engaging in a carefully managed and at times painful process of coalition building. Over time coalition members participated in growing the coalition, agreeing on a shared vision, and constructing permanent organizational structures. This required the development of trust and a sense of linked fates that rested on a form of imagined collective identification. Aunio and Staggenborg draw on Polletta and Jasper (2001, p. 284) to define

collective identity as an individual's cognitive, moral, and emotional connections with a broader community, category, practice, or institution. It is a perception of a shared status or relation, which may be imagined rather than experienced directly, and it is distinct from personal identities; although it may form part of a personal identity, it is formed through participation.

Joint action over time creates the context within which this imagined collective identity can emerge. As Melucci (1995) argues, collective identification is a dynamic process best understood as generated through sustained interaction.

Flesher Fominaya (2010) draws on Snow's (2001) work to indicate an additional element of collective identity, that of product. Snow argues that collective identity is also a product that is generated for movement participants and audiences to react to. This formulation is a key element of Flesher Fominaya's (2010) analysis of diversity in the global justice movement. She reminds us that movement adversaries and audiences do not respond to the collective identity of a movement as it is experienced by members; rather, they respond to the visible expression and projection of political content which is only in some cases defined in terms similar to the collective identity of the movement. In other words, the process of collective identity formation is an intramovement phenomenon even though it is conditioned and constructed in interaction with the broader political field. Here she warns against confusing intra-movement collective identity processes with the publicly projected movement identity.

However, in some cases the construction of that collective identity is a central, explicit goal of the movement that is then strategically employed as a political tool (Flesher Fominaya, 2010, p. 379). Interview data and the Platform's annual work programme confirm that the coalition states as a core objective that ' $[\mathrm{t}]$ he collective identity of civil society organizations (CSOs) is strengthened and communicated effectively' (Social Platform, 2011a, p. 8). Running an effective Platform is also listed as a core objective to be delivered by 'communicating more effectively what Social Platform members intend to achieve together' (Social Platform, 2011a, p. 9). As a member of the Platform team commented, 'Our intent is to get our members a bit closer to each other and also to make them aware that their issues are connected to one another' (Interview with Platform secretariat, September 2012). Growing a form of collective identification for the Platform is to be achieved through '[s]upporting members to develop mutual understanding and by sharing information and skills' (Social Platform, 2011a, p. 6). This focus on growing a sense of solidarity and mutual understanding is connected to one of the Platform's three strategic goals: that of strengthening the social civil society sector (Social Platform, 2011a, p. 8). In other words, developing a form of collective identification across what has been a fragmented and diverse sector is seen as part of a broader strategic goal to influence EU policy.

This objective is even more explicitly detailed in the Platform's Strategic Orientation 2014-2020 that acknowledges the growth in size and complexity of the coalition now requiring 'a framework to help ensure consistency of purpose and action'(Social Platform, 
2013a, p. 2). The framework lists a series of objectives aimed to 'provide coherence, focus and direction to all of the activities ... and help create a sense of belonging to a community that encompasses the various identities and interests of our members' (Social Platform, 2013a, p. 2). Here community is discursively constructed to be broad enough to contain a variety of identities and interests as an intra-movement product but at the same time understood as a prerequisite to outwardly focused strategic efforts.

The Platform also reoriented its thematic focus towards five different 'strands' that underpin its work programme, namely inclusion, rights, services, employment, and civil dialogue. These strands intersect with specific campaign areas. This cross-cutting of campaigns with thematic priorities and elements of EU policy is suggested by the Platform director 'to provide for more a holistic approach on social policies as this allows us to show the interrelation between the different policy areas of our members and the connection to EU policy' (Interview with Platform Director, 2012).

This effort to tie organizations together and to foster advocacy that reflects the intersectional nature of many social problems is also a strategy to advance and broaden members' reach across a wider area of EU agencies and policy contexts. In this way, growing a sense of imagined belonging to this community is both a strategic and an epistemological goal. It also requires a buy-in to a methodology that asks organizations in this space to seek out interconnections between their issues and constituencies and those of other member organizations. Thus, this is also about providing an intellectual context for interrelating different policy areas, a deliberative space for processes to occur that allow participants to become invested in a common decision, and ultimately a context for the crafting of a coordinated or united front to external adherents.

We can see the dynamics of collaboration that I argue are constitutive of this form of community when we focus on specific campaigns and common positions that the alliance has generated. Campaigns are a central feature of social movements (dellaPorta \& Rucht, 2002; Staggenborg \& Lecomte, 2009) and are important not only in achieving goals, but also in mobilizing communities and maintaining movements. The Platform has worked in many of these roles to generate a form of agreement around at times divisive issues including common positions on the revision of EU legislation prohibiting discrimination.

Working groups provide the context where policy issues are debated and common positions are constructed. Common positions take the form of technical documents that aim to provide expert knowledge to policy-makers and politicians but also contain elements of more confrontational campaigning. A closer reading of internal debates within these working groups sheds light on how the processes of constructing a form of collective identity and community are marked with contests over the content and meanings of the common positions that are generated.

\section{Working groups}

Research has affirmed that internal structures are a key element in supporting the maintenance of diverse coalitions. Such structures need to be organized in a way that avoids explicit competition but allows at the same time for meaningful participation (Staggenborg, 2010 , p. 323). Wood's (2005) work on the transnational coalition Peoples Global Action detailed how diverse organizations developed a strategy of working together on living documents that were continually revised and that provided a mechanism for creating collective identity which helped maintain the coalition. In the Platform's case, divisions 
between Platform members on issues including membership criteria, the primacy of different aspects of inequality within the Platform's value statement, and competition for EU funds had periodically threatened to fracture the alliance (Cullen, 2010). One specific innovation introduced by a former director to deal with such conflicts was the introduction of the system of working groups where, in similar terms to Wood's case, participants worked together on a form of 'living document'.

Working groups ${ }^{6}$ give an insight into the central role played by the secretariat in building cohesion, collective identification, and community. When asked about building consensus across such a large and diverse membership, a policy officer stated that over time the secretariat had figured out where the fault lines were. In her words,

It is now up to us to know where the conflicts are -to diffuse issues early on and, where it makes sense, involve external people to build expertise and diffuse disagreement. Working groups have been a good space to achieve this. (Interview with policy officer, May 2014)

Platform working groups are open to all members, meet quarterly, and are organized around different core campaigns of the Platform. Their function is to identify and propose areas of work, determine the direction and timing of any action, and ultimately draft policy papers (Social Platform, 2012a, p. 3). Three central working groups that had gained permanent status were the Working Group on Fundamental Rights and NonDiscrimination (WGFRAND) (renamed in 2013 Working Group on Fundamental Rights and Equality [WGFRE]), the Working Group on Social Policy (WGSP), and the Working Group on Social Services of General Interest (WGSSGI). Working group members communicate between meetings but officially interact on a quarterly basis in scheduled meetings where European Parliamentarians, European Commission officials, and experts are invited to contribute. Importantly working groups can be seen as contexts where coalition work takes place and where member organizations debate and deliberate on policy issues. They are also, in a more formal mode, the context through which members can access high-level EU officials, network with other members, and become exposed to specific external forms of expertise.

An audit of members' participation suggests that there is a cross-pollination of social service, advocacy, and anti-discrimination organizations across both WGFRE and WGSP. However, there is slightly less attendance of anti-discrimination NGOs at the WGSP meetings. The WGSSGI attracts few organizations that are not explicitly in the job of providing social services. When asked about their motivations for participating in working groups, one Platform member stated,

Our alliances need to push out beyond usual suspects and the Platform and its working groups are good for this. These work well because on the whole there now exists commonality, solidarity and knowledge of each other. (Interview with NGO member, September 2011)

The opportunity to attend working groups on issues outside of a member's traditional focus is also understood here as a chance to move beyond the obvious allies and as a way of 'educating' other members on issues that an organization has an expertise in and is eager to gain new sources of support to advance. Another Platform member 
remarked that working groups were a 'place for us to train others on issues like violence against women' (Interview with EWL, September 2011).

Working groups and the web of meetings that accompanied them also provide the context where organizations calibrate their networking in this ideologically diverse coalition. This is particularly important for advocates on issues such as gender equality where some members hold differing positions on issues such as family composition. As the secretary general of the largest gender equality NGO commented, 'In the Platform we try to participate in as many working group as we can, but fundamentally we tend to use this space to shift between bilateral and multilateral links for different topics.' She continued,

We work with COFACE [a family rights NGO] on some issues. With CARITAS [a Christian social justice NGO] we avoid reproductive rights but link in with them on poverty, and then look to IPPF [International Planned Parenthood] for a different set of connections. (Interview with EWL, September 2011)

The EWL also used the working group structures to gain political support for its own campaign to combat violence against women, enlisting more than half of the Platform members to sign its petition calling for a European Year on Ending Violence Against Women (Social Platform, 2011e). More recently the EWL working in the context of an Employment Working Party (EMPLWP), a subgroup of the WGSP, raised the issue of a stalled EU maternity leave directive and, in coalition with COFACE, campaigned for a European year for reconciling work and family life (Social Platform, 2013b). Other mini-coalitions emerged around the efforts of Platform members working on discrimination and equality issues within the WGFRAND to influence EU anti-discrimination legislation and funding.

The Platform has also worked to craft campaigns that enable its members to transcend specific working groups and identify with broader structural analyses of equality and social justice. Working groups in themselves have worked as sites for the exposure of Platform members to academic social scientific expertise with training on concepts including multiple discrimination, equality mainstreaming, intersectionality, bias violence, and care as a social construct. As a member of the Platform secretariat remarked,

Working groups now provide a context for training for our members also where they can learn from each other and perhaps acknowledge the interconnected nature of many of the issues they focus upon individually. (Interview with Platform member, September 2011)

Platform members do see the coalition as a venue to build capacity, for example, in access to technical expertise. This is made clear by a Platform member referring to the EU overhaul of its economic governance which afforded a degree of public consultation on the highly technical reconfiguration of the market system that governs EU member state economic policy-making. He noted, 'NGOs are quite new to be consulted on budgetary issues. We have little experience of the technical elements, and the Platform is a good space to help fill this gap' (Interview with Platform member, 2012).

Aside from working group structures, carefully choreographed campaigns and common positions illustrate some elements of how the Platform works as a site where coalition 
work takes place, consensus is crafted, and a form of imagined collective identification and community is enacted.

\section{The Platform's recommendations on care}

The Platform's annual theme for 2011 was that of care. This theme afforded the coalition a unique opportunity to pull its members 'closer together' whereby working group structures and the secretariat collaborated in a year-long process of commissioning external expertise, surveying members and developing a concept paper that was then debated to construct a common set of recommendations. This was not without difficulties: The exercise of soliciting input and evidence for the common position was not an easy one. As one Platform policy officer commented, 'This is a more diverse and contentious working group with many differences of opinion and tough struggles to agree on a shared approach' (Interview with policy officer, September 2011).

Feantsa, the organization representing service providers for the homeless, and Eurodiaconia, a social service organization from a Catholic social perspective, coordinated the working group on care. While the working group was heavily populated by social service provider members, other equality-oriented NGOs including the EWL, Eurochild, and ENAR were also present.

The care paper was, as a Platform member commented, an effort to 'try and bridge the different fields' and to provide an opportunity for collaboration between advocacy and social service organizations who often struggled to find common ground. As a member of the Platform secretariat suggested,

We are trying to make more and more links between members on the position on care. All three working groups were consulted as care is an equality issue but also a social policy one. (Interview with a member of the Platform secretariat, September 2011)

Responding broadly to the breadth of Platform members and their constituents, care givers, care users, and care workers are distinguished in the position paper as central actors. Care is also conceptualized as a gendered phenomenon with references to the gender care burden and the feminized nature of paid work in the care sector. All of these issues are linked in the statement,

We call to vindicate the fundamental rights of care users. This can be accomplished when you invest in services, train and provide decent work conditions for care workers and sufficient support for families who care. (Social Platform, 2011b, p. 2)

The document also casts a wide net across a range of equality issues including discrimination in access to care services, highlighting also the overuse of residential care in some member states for Roma children and other vulnerable groups (Social Platform, 2011c).

The Platform's recommendations on care exemplify the coalition's effort to build a community response, and illustrate how members collectively identified as a cross-sectoral force that could advocate on a complex issue from a variety of perspectives. For the Platform secretariat, the exercise helped to remind members of an added value to 
coalition membership by enabling them to make connections between and across their causes. This said, the decision to choose care as a thematic priority does reflect the prevalence of the social service provider NGOs in the coalition. This theme was also chosen at the height of the Eurocrisis and reflects a strategic effort to ground the Platform and its members at a time when more specific campaigns had found little traction.

A second campaign and common position on bias violence illustrates another carefully choreographed effort to pull members 'closer together'.

\section{The Platform's position paper on bias violence}

The WGFRAND, constituted by a majority of anti-discrimination and equality NGOs, took a more central role in the Platform's common position on bias violence. The decision to work on the issue of bias violence was taken as way of activating a number of members' shared interests in discrimination as a source of violence and of pulling social service NGOs into considering the issue in a cross-sectoral way. It was also a response to stalled efforts to advance EU initiatives on violence against women, a revision of anti-discrimination legislation, and to capitalize on EU-level frameworks to protect the victims of hate crimes, including a recent EU Victims Directive (Social Platform, 2012b, p. 3). The process of constructing the common position involved surveying members on their understandings and approach to the issue of violence and was followed up with a training session conducted by an academic expert on bias violence (Social Platform, 2011d). A concept paper was then drafted by the secretariat and the coordinator of NGOs PICUM and ILGA and used as a reference point for in-depth interviews with members.

Reporting the results of the survey, an internal briefing note drew attention to the diversity of Platform membership:

Platform members have developed specific approaches to violence, because their fields of experience are diverse. Some members are networks of community based organizations, working on one specific ground of discrimination and its associated forms of bias violence. Other members build their actions on the basis of social expertise, related to a profession or a social status. As a result, most members have developed specific but unrelated concepts to name the particular forms of discriminatory violence that they want to address. (Social Platform, 2011d, p. 1)

As one member of the Platform remarked,

In this process we were interested to see how our coalition partners treated the issue of violence and how much it varies differently by these sectors and of course to make the argument for it to be interlinked to a much higher degree. (Interview with Platform member, September 2011)

Analysis of the minutes of the working group reveals a lively debate on how best to frame a common response. The EDF pushed for violence to be linked to vulnerability understood as a characteristic rather than stemming from a status position. IFSW representing social workers suggested degendering the text as 'there is too much focus on women', arguing for perpetrators and victims to be used instead. While ENAR advocated for violence based on religion to be given a higher profile in the document, ERIO (Roma 
rights) and PICUM suggested that institutionalized violence (repression by state agents) should be included.

The process of constructing the common position also revealed how members were attempting to influence a range of different EU-level initiatives on violence. Aware of the unevenness of these approaches that included, for example, small-scale programmes to combat violence against women and broader European policy on hate-motivated violence and crime, the common statement aimed to push the EU to develop a more coherent and comprehensive strategy by 'advancing a common agenda of policy recommendations to fight any form of violence' (Social Platform, 2012c, p. 2). The final definition of bias violence was agreed as, 'acts of violence with a bias motive, or triggered by prejudice, or ingrained in unequal structures in society that constitute a serious breach of human rights' (Social Platform, 2012b, p. 3). The process of negotiating the position exposed the members to each other's specific understanding of violence and then required signees to consent to a document that included an umbrella concept while at the same allowed for an acknowledgment of mutually reinforcing dynamics of vulnerability to violence.

For the Platform secretariat, the exercise involved inviting unexpected members to talk about their connections to violence: 'It could be in relation to poverty, mental health ... or members that do not work on the issue so much' (Interview with policy officer September, 2011). This in itself was understood to have increased mutual understanding and an interest in potential connections to be made between members unused to collaborating closely. As the briefing note concluded,

Further developing our work on violence has the potential to show EU decision makers that we, as the Social Platform, can speak with one voice and promote a consistent approach on the basis of rich expertise, instead of simply listing claims for actions to address a range of similar but separated forms of violence. Making this actually happen requires that certain conditions are met.-The Platform's members have to agree on a common language to build their common position. This means finding common concepts to describe the forms of violence we want to combat, and articulating positions which can be used consistently with the members' own materials. (Social Platform, 2011d, p. 14)

On this latter point the intent is for the common position to have an explicit influence on the content of the materials of individual member organizations. In policy terms the Platform's common position and, in particular, its linking of equality, discrimination, and violence was taken up in EU debate on hate crime legislation and received support from the European Parliament. ${ }^{7}$ Allied campaigns include advocacy for EU equality data collection to expose under-reporting of bias violence and hate crimes (Social Platform, 2014a, 2014 b). These campaigns also mark a shift in pulling diverse organizations together to generate common understandings and to commit collectively to a community response on complex and contentious issues.

\section{Discussion: collective action frames within a professional SMO community}

A clear objective of the Platform articulated through its campaigns and common positions is to bring 'its members closer together'. For Aunio and Staggenborg (2011), transnational 
social movement communities—although differentiated spatially and tactically—must at a basic level operate a form of 'imagined community' forged through a sense of collective identification. For professional SMO communities this may be less about occupying a building or orchestrating a street protest but rather mounting joint campaigns drawing on pooled expertise, shared understandings, and connections, often to elites and institutional contacts. Analysis of the content of Platform positions reveals an explicit effort to 'strengthen the collective identity of the social civil society sector' through capacity building aimed at forging a sense of the connections between the specific issues/constituents that organizations represent.

One way to make sense of these processes is through a brief analysis of the framing employed. In her work on the alter globalization and transnational feminist movement, Hewitt (2011, pp. 78-80) argues that activists in transnational spaces commonly draw on both oppositional or 'anti' frames and movement process/capacity-building frames that are internally focused frames in their solidarity efforts. What characterizes 'anti' frames is their sole focus on the enemy or the problem; however, they are often short on proposing solutions (Hewitt, 2011, pp.85-86). An example of an 'anti' frame is an emphasis on the loss of a social dimension within the European project, which is a common frame used by the Platform and its members particularly in its broadest external communications. The strategic advantage of this kind of frame is its solely diagnostic nature and the lack of a requirement for consensus on solutions or even necessarily issue priorities. However, while these broad oppositional frames may serve an important function in promoting dialogue and connection, they suffer from an inherent flaw in that they fail to articulate what a movement is for and offer little to sustain a durable form of allegiance across diverse causes. If movement actors cannot successfully articulate shared solutions to the problems they identify, they may leave themselves vulnerable to external threats that weaken their capacity to resist hegemonic frameworks (Hewitt, 2011, p. 82).

In this sense it is a second form of framing-that of capacity-building and process frames-that seems to generate most potential for nourishing and strengthening such coalitions. In this framing, intra-movement difference and diverse expertise are explicitly mentioned as strengths that underpin a movement's capacity to develop sophisticated yet cohesive campaigns representing a broad spectrum of groups and issues. In the context of the Platform in its positions on care and bias violence, it is the diversity and richness of its members' expertise and claims that are publicly celebrated while the connections between their causes are emphasized. Care and violence in particular are unpacked as cross-sectoral and intersectional concepts that all members of the coalition are encouraged to find a stake in. As Hewitt (2011, p. 90) argues, inherent in capacity building and movement process work is an understanding that different movement actors play different roles and have different priorities and that the broader movement needs all such actors in order to succeed.

\section{Conclusion}

The Europeanization of OCS has included incentives for coalition formation. This article has aimed to make sense of what happens when diverse NGOs collaborate at EU level over a significant period of time. Can collaboration shift identities and problem definitions employed by NGOs? Ultimately, can the forms of coalition that emerge at the transnational level between NGOs be understood as a form of professional SMO community? 
Drawing on the case of a diverse coalition of EU social NGOs, the Social Platform, this work suggests that in organizational, strategic, and tactical terms this coalition satisfies the criteria for consideration as a professional SMO community working on the transnational level. These criteria include the existence of professional leaders operating in multileveled networks, the use of insider strategies, and in organizational terms, structures where members deliberate and craft common campaigns. An essential component of the professional SMO community is the existence of a form of collective identification and community constructed through repeated interaction in the context of coalition work.

Analysis of the deliberation and outputs of Platform working groups suggest the existence of a form of collective identification and community that allows diverse organizations to deliberate and reach a consensus on complex and potentially contentious issues. Externally, this coalition work has enabled the construction of a cohesive voice for the EU social NGO sector where organizations generate and project a community response to EU officials and member state governments. While the benefits of coalition are clear in terms of greater strength when voicing shared positions, internally this form of community has afforded forms of capacity building including information sharing, pooling of resources, and access to external expertise.

However, the construction of this collective identification is not a linear or even finished process, and may be open to charges of homogenization or managerialism that are associated with the organizational isomorphism that accompanies the professionalization of transnational NGOs. Imbalances between larger and smaller member organizations and tensions related to how the most prominent members balance representing their own interests and 'speaking on behalf of the Platform' also continue to shape coalition dynamics. Power plays and asymmetries in terms of resources and voice across the membership, although not explicitly examined here, are important factors shaping the internal functioning and external output of this coalition. From this perspective understanding how collective identification as an internal process and an external product is generated, via internal communicative processes and shaped by organizational imperatives, can help shed light on the internal positioning of actors and external influence of this coalition.

This work also suggests that transnational OCS coalition formation should be seen less in terms of loosely connected networks and more as organizational forms with more permanent structures and greater member commitment. Along these lines, while members of the Platform have over the years waxed and waned in terms of their commitment to the coalition, levels of attrition have been minimal. Importantly this analysis suggests that analysis of intra-organizational dynamics of coalitions is useful in illustrating how transnational NGO coalitions are increasingly bound by a network of interdependencies that generate opportunities for community building with other organizations that have implications for their capacity to navigate a complex, technocratic, multilevel political opportunity structure.

\section{Disclosure statement}

No potential conflict of interest was reported by the author.

\section{Notes}

1. Johansson and Lee suggest that two-thirds of the Platform membership receive $50 \%$ or more of their budget from the EU, while $40 \%$ rely on EU funds for over $75 \%$ of their budget (2012, p. 25). 
2. Membership criteria include a focus on social issues, commitment to a value statement, and representation in the majority of EU member states.

3. Over half were established between the mid-1980s up to the mid-1990s as a function of EU programmes and the expansion of EU competencies during this period in the area of social and employment issues. Few new groups were established since the late 1990s (Johansson \& Lee, 2012, pp.11-13).

4. Aunio and Staggenborg (2011) identify different forms of social movement community, distinguishing between professional communities, grassroots communities, and conscience communities, differentiated on the bases of location, repertoire, and networks but all critical to the construction of transnational social movement identities and campaigns.

5. The Platform is represented in 18 EU advisory groups (Social Platform, 2013a, p. 14).

6. In 2014 working groups were reorganized and renamed as task forces.

7. The European Parliament adopted a nonbinding resolution on hate crime and bias violence invoking the demands made in the Platform's common position on 14 March 2014.

\section{References}

Aunio, A. L., \& Staggenborg, S. (2011). Transnational linkages and movement communities. Sociology Compass, 5(5), 364-375.

Bandy, J., \& Smith, J. (Eds.). (2005). Coalitions across borders: Negotiating difference and unity in transnational struggles against neoliberalism. Lanham, MD: Rowman and Littlefield.

Bee, C., \& Guerrina, R. (2014). Participation, dialogue and civic engagement: Understanding the role of organized civil society in promoting active citizenship in the European Union. Journal of Civil Society, 10(1), 29-50.

Berg, L. B. (2007). Qualitative methods for the social sciences. Boston: Allyn and Bacon.

Cullen, P. (2005). Conflict and cooperation within the Platform of European Social NGOs. In J. Bandy \& J. Smith (Eds.), Coalitions across borders: Negotiating difference and unity in transnational struggles against neoliberalism (pp. 71-94). Lanham, MD: Rowman and Littlefield.

Cullen, P. (2010). The platform of European social NGOs: Ideology, division and coalition. Journal of Political Ideologies, 15(3), 317-331.

dellaPorta, D., \& Rucht, D. (1995). Left-libertarian movements. In J. C. Jenkins, \& B. Klandermans (Eds.), The politics of social protest (pp. 229-72). Minneapolis: University of Minnesota Press.

dellaPorta, D., \& Rucht, D. (2002). The dynamics of environmental campaigns. Mobilization: An International Quarterly, 7(1), 1-14.

Diani, M. (2013). Organizational fields and social movement dynamics. In J. van Stekelenburg, C. Roggeband, \& B. Klandermans (Eds.), Dynamics, mechanisms and processes the future of social movement research (pp. 145-168). Minneapolis: University of Minnesota Press.

Diani, M., \& Bison, I. (2004). Organizations, coalitions, and movements. Theory and Society, 33, 281-309.

Diani, M., \& Pilati, K. (2011). Interests, identities, and relations: Drawing boundaries in civic organizational fields. Mobilization, 16, 265-282.

Dur, A. (2008). How much influence do interest groups have in the EU: Some methodological considerations. In B. Kohler-Koch, D. De Bièvre, \& W. Maloney (Eds.), Opening EU governance to civil society_Gains and challenges (pp. 45-67). Mannheim: Connex.

Favell, A., \& Guiraudon, V. (2011). Sociology of the European Union. Basingstoke: Palgrave.

Flesher Fominaya, C. M. (2010). Creating cohesion from diversity: The challenge of collective identity formation in the global justice movement. Sociological Inquiry, 80(3), 377-404.

Geyer, R. (2001). Can European Union (EU) social NGOs co-operate to promote EU social policy? Journal of Social Policy, 30(3), 477-493.

Greenwood, J. (2007). Organised civil society and democratic legitimacy in the EU. British Journal of Political Science, 37(2), 333-357.

Guiraudon, V. (2001). Weak weapons of the weak? Transnational mobilization? Transnational mobilization around migration in the European Union. In S. Tarrow \& D. McAdam (Eds.), Contentious Europeans: Protest and politics in an emerging polity (pp. 163-183). Lanham, MD: Rowman and Littlefield.

Hewitt, L. (2011). Framing across differences, building solidarities: Lessons from women's rights activism in transnational spaces. Interface: A Journal for and About Social Movements, 3(2), 65-99. 
Johansson, H., \& Lee, J. (2012, November 29). Challengers to the crisis: Civil society organizations' aims, strategies and activities to revitalize the EU 'social dimension. Paper Presented at the ESA Political Sociology Conference, Milan.

Kendall, J. (2010). The limits and possibilities of third sector Europeanisation. Journal of Civil Society, 6(1), 39-65.

Kohler-Koch, B., \& Quittkat, C. (2013). De-mystification of participatory democracy EU governance and civil society. Oxford: Oxford University Press.

Kroger, S., \& Friedich, D. (2013). Democratic representation in the EU: Two kinds of subjectivity. Journal of European Public Policy, 20(2), 171-189.

Maney, G. M. (2012). Agreeing for different reasons ideology strategic differences and coalitional dynamics in the Northern Ireland civil rights movement. In G. Maney, R. Kutz-Flamenbaum, D. A. Rohlinger, \& J. Goodwin (Eds.), Strategies for social change (pp. 170-196). Minneapolis: Minnesota University Press.

McCright, A. M., \& Dunlap, R. E. (2008). The nature and social bases of progressive social movement ideology: Examining public opinion toward social movements. The Sociological Quarterly, 49, 825-848.

Melucci, A. (1995). The process of collective identity. In H. Johnston \& B. Klandermans (Eds.), Social movements and culture (pp. 41-63). Minneapolis: University of Minnesota Press.

Polletta, F., \& Jasper, J. A. (2001). Collective identity and social movements. Annual Review of Sociology, 27, 283-305.

Ruzza, C. (2004). Europe and civil society: Movement coalitions and European institutions. Manchester: Manchester University Press.

Ruzza, C. (2011). Social movements and the European intermediation of public interest groups. Journal of European Integration, 33(4), 453-469.

Ruzza, C., \& Bozzini, E. (2008). Organised civil society and European governance: Routes of contestation. European Political Science, 7(3), 296-303.

Snow, D. (2001). Collective identity and expressive forms. Oakland: University of California Press.

Social Platform. (2011a). Work programme 2012. Retrieved November 2011, from http://cms.horus.be/files/ 99907/MediaArchive/About_Us/Social\%20Platform\%20Work\%20Programme\%202012\%20summary.pdf

Social Platform. (2011b). Social platform annual conference on care we care, how can EU care? December 9, 2011. Retrieved December 21, 2011, from http://cms.horus.be/files/99907/MediaArchive/Events/Annual_ conferences/Annual_Conference_on_CARE_2011/Social\%20Plaform\%20conference\%20on\%20care_Min utes $\% 20$ of $\% 20$ main $\% 20$ messages.pdf

Social Platform. (2011c). Recommendations on care-As voted in the steering group. Retrieved November 2011, from http://cms.horus.be/files/99907/mediaarchive/events/annual_conferences/annual_conference_ on_care_2011/111031_sp\%20recommendations\%20on\%20care_final.pdf

Social Platform. (2011d). Briefing notes towards a common position on violence. October 2011. Brussels.

Social Platform. (2011e). Fundamental rights and anti-discrimination (WGFRAND) working group draft minutes of meetings January 10, 2011; May 4th, 2011; June 21st, 2011; September 22nd, 2011. Brussels.

Social Platform. (2012a). What we do and what can social platform offer to its members? Brussels. Retrieved November 21, 2012, from http://www.socialplatform.org/Page_Generale.asp?DocID=8146

Social Platform. (2012b). A social platform position paper: Towards EU action on all forms of bias violence. Adopted by social platform steering group on September 25, 2012, Brussels.

Social Platform. (2012c). Fundamental rights and non-discrimination working group (WGFRAND) minutes of meetings, September 13, 2012; May 8th 2012. Brussels.

Social Platform. (2013a). Strategic orientation 2014-2016. Brussels.

Social Platform. (2013b). Social policy working group minutes March 1st, 2013. Brussels.

Social Platform. (2014a). Annual report 2013. Brussels.

Social Platform. (2014b). Task force on bias violence and hate crime: BRIEFING. Retrieved June 10, 2014, from http://www.socialplatform.org/wpcontent/uploads/2014/04/20140416_SocialPlatform_Briefing_Violence. pdf

Staggenborg, S. (1986). Coalition work in the pro-choice movement: Organizational and environmental opportunities and obstacles. Social Problems, 33(5), 374-390.

Staggenborg, S. (1988). The consequences of professionalization and formalization in the prochoice movement. American Sociological Review, 53(4), 585-605.

Staggenborg, S. (2010). Conclusion: Research on social movement coalitions. In N. Van Dyke \& H. J. McCammon (Eds.), Strategic alliances: New studies of social movement coalitions (pp. 316-329). Minneapolis: University of Minnesota Press. 
Staggenborg, S. (2013). Organization and community in movements. In J. van Stekelenburg, C. Roggeband, \& B. Klandermans (Eds.), Dynamics, mechanisms and processes the future of social movement research (pp. 125-143). Minneapolis: University of Minnesota Press.

Staggenborg, S., \& Lecomte, J. (2009). Social movement campaigns: Mobilization and outcomes in the Montreal women's movement. Mobilization, 14(2), 405-442.

Staggenborg, S., \& Taylor, V. (2005). Whatever happened to the women's movement? Mobilization: International Journal of Theory and Research About Social Movements and Collective Behavior, 10(1), 37-52.

Trenz, H. J. (2009). European Civil Society. Between participation, representation and discourse'. Policy and Society, 28(1), 35-34.

Van Dyke, N., \& McCammon, H. J. (Eds.) (2010). Strategic alliances: Coalition building and social movements. Minneapolis: University of Minnesota Press.

Wang, D., \& Soule, S. (2012). Social movement organizational collaboration: Networks of learning and the diffusion of protest tactics, 1960-1995. American Journal of Sociology, 117(6), 1674-1722.

Wood, L. (2005). Bridging the chasms: The case of people's global action. In J. Bandy \& J. Smith (Eds.), Coalitions across borders: Negotiating difference and unity in transnational struggles against neoliberalism (pp. 95-120). Lanham, MD: Rowman and Littlefield.

Yanacopulos, H. (2005). The strategies that bind: NGO coalitions and their influence. Global Networks, 5(1), $93-110$ 